\title{
Alteration of Reproductive Hormone Levels in Pregnant Sows Induced by Repeated ACTH Application and Its Possible Influence on Pre- and Post-natal Hormone Secretion of Piglets
}

\author{
Klaus-Peter BRÜSSOW ${ }^{1)}$, Falk SCHNEIDER ${ }^{1)}$, Ellen KANITZ2), \\ Winfried OTTEN ${ }^{2)}$ and Margret TUCHSCHERER ${ }^{2)}$
}

\author{
${ }^{1)}$ Department of Reproductive Biology and ${ }^{2)}$ Department of Behavioural Physiology, Research \\ Institute for the Biology of Farm Animals, D-18196 Dummerstof, Germany
}

\begin{abstract}
Prenatal stress has been seen as a reason for reproductive failures in pig offspring mostly originated or mediated by changed maternal functions. Experiments were conducted in pregnant gilts $(n=32)$ to characterize effects of elevated maternal glucocorticoids on the secretion of reproductive hormones (LH, progesterone) during the $1^{\text {st }}(\mathrm{EXP} 1), 2^{\text {nd }}(\mathrm{EXP} 2)$ and $3^{\text {rd }}(\mathrm{EXP} 3)$ trimester of pregnancy (TP). Transiently elevated cortisol release was repeatedly achieved by application of 100 IU adenocorticotropic hormone (ACTH) (Synacthen Depot $\left.{ }^{\circledR}\right)$ six times every second day beginning either on day 28 (EXP 1), day 49 (EXP 2) or day 75 of pregnancy (EXP 3). Glucocorticoid concentrations were examined in umbilical blood vessels of fetuses which mothers were subjected to $\mathrm{ACTH}$ at $2^{\text {nd }}$ and $3^{\text {rd }} \mathrm{TP}(\mathrm{EXP} 4)$. Furthermore, the pituitary function of newborn piglets of EXP 2 was checked by a LH-RH challenge test. In sows, LH concentrations were at low basal level (0.1-0.2 ng/ $\mathrm{ml}$ ) but with pulsatory release pattern during each TP. The number of LH pulses $/ 6 \mathrm{~h}(\mathrm{LSM} \pm \mathrm{SE}) \mathrm{of}$ saline treated Controls increased with ongoing pregnancy and decreased to the $3^{\text {rd }} \mathrm{TP}(1.3 \pm 0.2$ in EXP 1 vs. $2.0 \pm 0.1$ in EXP 2 vs. $1.4 \pm 0.1$ in EXP 3, p<0.05). After ACTH treatment the number of LH pulses left unchanged in Experiments 1 and $2(1.3 \pm 0.2$ and $1.5 \pm 0.1)$ and decreased in EXP $3(0.8 \pm 0.2$, $\mathrm{p}<0.05)$. Differences $(\mathrm{p}<0.05)$ were obtained comparing the LH pulse number of ACTH and saline treated sows at the $2^{\text {nd }}$ and $3^{\text {rd }} \mathrm{TP}$. Moreover, areas under the curve (AUC) of each LH pulse and of LH over baseline were significantly reduced by treatment. Levels of progesterone increased $(p<0.05)$ for 150 to 170 min after each ACTH application both in EXP 1 and EXP 2, but not in EXP 3. The mean progesterone concentration was different between trimesters, and ACTH and Controls ( $1^{\text {st }} \mathrm{TP}: 30.0 \pm$ 0.9 and $24.4 \pm 0.7 \mathrm{ng} / \mathrm{ml} ; 2^{\text {nd }} \mathrm{TP}: 35.5 \pm 0.9$ and $29.1 \pm 1.0 \mathrm{ng} / \mathrm{ml} ; 3^{\text {rd }} \mathrm{TP}: 13.6 \pm 0.2$ and $13.1 \pm 0.1 \mathrm{ng} / \mathrm{ml}$; $\mathrm{p}<0.05)$. In fetuses $(\mathrm{n}=87)$ recovered $3 \mathrm{~h}$ after ACTH or saline (EXP 4$)$, the plasma cortisol concentrations were significantly increased in umbilical vein $(93.7 \pm 5.5 \mathrm{vs}$. $47.0 \pm 5.3 \mathrm{nmol} / 1)$ and artery $(95.7 \pm 5.4 \mathrm{vs} .66 .4 \pm 5.4 \mathrm{nmol} / \mathrm{l})$, and in periphery $(46.8 \pm 5.3 \mathrm{vs} .27 .1 \pm 5.3 \mathrm{nmol} / \mathrm{l})$ compared to controls. Plasma ACTH concentrations, however, did not differ in fetuses of both treatment groups. Postnatal LH-RH challenge tests $\left(1^{\text {st }}\right.$ and $28^{\text {th }}$ day post partum) induced LH surges in female piglets $(\mathrm{n}=67)$ both of ACTH and saline treated sows, but did not differ between groups $\left(1^{\text {st }}\right.$ day: $7.2 \pm 0.8$ vs. $8.1 \pm 0.7 \mathrm{ng} / \mathrm{ml} ; 28^{\text {th }}$ day: $10.5 \pm 1.7$ vs. $\left.13.6 \pm 2.2 \mathrm{ng} / \mathrm{ml}\right)$. However, basal LH of piglets whose mothers were submitted to ACTH during $2^{\text {nd }} \mathrm{TP}$ was lower on $1^{\text {st }}$ day $(1.7 \pm 0.2 \mathrm{vs} .2 .3 \pm 0.2 \mathrm{ng} / \mathrm{ml}, \mathrm{p}<0.05)$ but not on $28^{\text {th }}$ day $(1.0 \pm 0.2$ vs. $1.1 \pm 0.2 \mathrm{ng} / \mathrm{ml})$. However in both groups, the basal LH was always higher on $1^{\text {st }}$ as on $28^{\text {th }}$ day $(\mathrm{p}<0.05)$. Thus, chronic intermittent ACTH administration is able to influence the release pattern of maternal reproductive hormones. However, these findings demonstrate that these effects are dependent on the stage of pregnancy. Furthermore, it was shown that maternal cortisol can cross the placenta during gestation and thus may affect maternal-fetal interactions and, as a result, reproductive function of offspring.
\end{abstract}

Key words: Luteinizing hormone, Progesterone, adenocorticotropic hormone (ACTH), Pregnancy, Stress, Fetus, Pig 
S tressful stimuli activate in mammals the hypothalamic-pituitary-adrenal (HPA) axis which leads to the release of corticotrophin releasing factor (CRF), adenocorticotropic hormone (ACTH), and cortisol. Corticoids (corticosterone and cortisol) are the main stress response with permissive, suppressive, stimulatory or preparatory effects [review: 1]. Besides these effects, cortisol plays an essential role for cell cycle regulation in many organs, binds to the aldosterone receptor (MC-R) in mineralocorticoid-sensitive tissues [2], and is essential during inflammation preventing an excessive activation of the immune system [3]. Cortisol is a responsible steroid in swine as well. During pregnancy stress may influence the function of the porcine placenta and corpora lutea, which are steroidogenic tissues involved in the maintenance of pregnancy $[4,5]$. Moreover, prenatal stress may exert lasting effects on gonadal function, behaviour, regulation of the HPA axis and on immuno-competence of the offspring [6-9]. Stress related effects on developing fetuses and on coming reproductive function of offspring may differ between various periods of the pregnancy and the ongoing differentiation of the fetal reproductive tract [10-12]. Despite comprehensive research the mechanisms by which stressors affect reproductive function in swine are not fully known [13].

Although single or repeated acute stress (e.g. restrain of snout, electric foot shock, transportation or jugular puncture) induces elevated cortisol levels, it may not result in deleterious effects [1416]. Studies with different models of stress imitation have demonstrated that both administration of ACTH or cortisol impaired reproductive function in female pigs when given in a way which resulted in a sustained elevation of cortisol in plasma [17-19]. Furthermore, cortisol was shown to affect the LH secretion preferentially by reducing the frequency and amplitude of GnRH pulses [20, 21], and by effects at pituitary level [22].

In pregnant pigs, the concentration of maternal LH is low and with minor pulsatile secretion [2326]. But all in all, only little information is available on gonadotropin concentration during porcine pregnancy and during stressful conditions of pregnancy.

The objective of this study was to characterize the secretion pattern of $\mathrm{LH}$ and progesterone $\left(\mathrm{P}_{4}\right)$ throughout the $1^{\text {st }}, 2^{\text {nd }}$ and $3^{\text {rd }}$ trimester of pregnancy (TP), and under the influence of elevated cortisol levels induced by repeated ACTH injections. Further, the effects of elevated maternal glucocorticoids on cortisol concentrations in umbilical blood vessels of fetuses was evaluated, and the pituitary function of newborn piglets checked by a LH-RH challenge test.

\section{Materials and Methods}

All procedures involving animal handling and treatment were approved by the Committee for Animal Use and Care of the Ministrial Department of Mecklenburg-Vorpommern, Germany.

\section{Animals, hormonal treatment and blood sampling}

Altogether 32 pregnant primiparous Landrace sows were used in four experiments (EXP 1. n=8, EXP 2. $n=8, E X P$ 3. $n=10, \operatorname{EXP} 4 . n=6)$. Sows were held in individual pens beginning on day 11 after A.I. (= day 11 of pregnancy). They were fitted with indwelling jugular catheters [27] under ketamin/ xylazin anaesthesia (Ursotamin $\AA$, Xylazin ${ }^{\circledR}$, Serumwerk Bernburg, Germany) either between days 24-25 (EXP 1; $1^{\text {st }}$ trimester of pregnancy-TP), days 46-47 (EXP 2; $2^{\text {nd }}$ TP) or days $83-84$ of pregnancy (EXP 3; $\left.3^{r} \mathrm{~d} T \mathrm{~T}\right)$. Sows were fed a commercial food for pregnant sows and had free access to water.

Six i.m. injections, each of 100 IU ACTH (Synacthen ${ }^{\circledR}$ Depot, Novartis Pharma, Brussels, Belgium) or saline, were given at 08:00 every two days beginning on day 28 (EXP 1), 49 (EXP 2) or 85 of pregnancy (EXP 3), respectively. In each experiment, the half of animals received ACTH or saline (Controls). Blood samples were drawn on treatment days immediately before and every 10 min after ACTH administration from 08:00 to 14:00.

In EXP 4, only one injection of 100 IU ACTH (n= $3)$ or saline $(n=3)$ was given on day 65 of pregnancy at 08:00. Three hours post-ACTH injection, all fetuses were recovered by Caesarean section lege artis under ketamin/xylazin anaesthesia. In total, 42 fetuses from ACTH-treated and 45 fetuses from Control sows were recovered. Blood samples were obtained $3 \mathrm{~h}$ after ACTH or saline application via venipuncture from the external jugular vein of the sow, and from the umbilical vein and artery of each fetus. Additionally, blood samples were obtained from each fetus after decapitation. Cortisol 
concentrations were also measured in umbilical vein and artery of 24 fetuses (each 2 male and 2 female) from $6 \mathrm{ACTH}$ and saline treated sows of EXP 3 on day 105 of pregnancy.

Postnatal LH-RH challenge tests (EXP 5; injection of $5 \mu \mathrm{g}$ Gonavet $\AA$, Veyx Pharma, Schwarzenborn, Germany) was done in 67 female piglets, whose mothers were subjected to repeated ACTH application during the $2^{\text {nd }} \mathrm{TP}$, on day 1 and day 28 post partum (p.p.). Blood samples $(1 \mathrm{ml})$ were drawn via venipuncture from the external jugular vein immediately before and 30, 60, 120 and 180 min after GnRH injection.

The blood samples were collected in ice-cooled plastic syringes containing EDTA-Kalium as anticoagulant (KABE, Germany). Samples were centrifuged at 2,000 to 4,000 rpm for $15 \mathrm{~min}$ at $4 \mathrm{C}$, plasma portioned in aliquots and stored until analysis at -20 or $-80 \mathrm{C}$.

\section{Hormone analyses}

LH was determined by a non-isotopic electrochemiluminescence immunoassay (ECLIA). A sandwich type assay was performed according to the method for the determination of bovine $\mathrm{LH}$ [28]. The ECLIA was carried out in $12 \times 75 \mathrm{~mm}$ polypropylene tubes (Minisorb PE; Nunc, Roskilde, Denmark). An N-hydroxy-succinimide ester of ruthenium(II)-tris-bipyridine chelate (Ru-ester) was used to label the monoclonal antibody 517 B7 against bovine $\mathrm{LH}(\mathrm{b}-\mathrm{LH})$ as recommended by the manufacturer (IGEN, Gaithersburg, MD). The standard porcine-LH ( $\mathrm{p}-\mathrm{LH}$, iodination grade) and polyclonal rabbit-anti $\mathrm{pLH}$ were provided from Biotrend (Cologne, Germany). The Ru-labelled monoclonal antibody $(25 \mu \mathrm{l})$ and polyclonal antibody $(50 \mu \mathrm{l})$ were allowed to bind to the hormone (standard/sample, $20 \mu \mathrm{l}$ ). Determination of the standard curve was started at $12.8 \mathrm{ng} / \mathrm{ml}$ and diluted throughout $0.025 \mathrm{ng} / \mathrm{ml}$. After overnight incubation $50 \mu \mathrm{l} /$ tube of secondary antibody, sheep anti-rabbit IgG coupled to magnetic beads (50 $\mu$; Dynal, Oslo, Norway), was added and mixed. Finally, the intensity of chemiluminescence was measured using an Origen ${ }^{\mathrm{TM}} 1.5$ analyser (IGEN). The ECLIA ran for approximately $1 \mathrm{~h}$ per carousel sample changer fitted with 50 samples. The sensitivity of the method was calculated to be 0.03 $\mathrm{ng} / \mathrm{ml}$. The intra- and interassay $\mathrm{CV}$ were 6.1 and $8.7 \%$, respectively.

The peripheral plasma $\mathrm{P}_{4}$ level was analyzed using a competitive single-antibody ${ }^{3} \mathrm{H}$-RIA without extraction [28]. The tracer, $\left[1,2,6,7-{ }^{3} \mathrm{H}\right]$ progesterone, was purchased from Amersham Biosciences Europe (Freiburg, Germany). The antibody was raised in rabbits by immunisation with a 11-hydroxy-progesterone conjugate and further purified by affinity chromatography on protein A superose (Amersham Pharmacia Biotech). As result, cross-reactivities to related steroids, e.g. pregnenolone, androstendione, cortisol, were lower than $0.4 \%$. The CV for intraassay and intra-assay were 7.7 and $10.1 \%$, respectively.

Plasma cortisol concentrations were measured in duplicates using a commercial available ${ }^{125}$ I-RIA kit (DRG International Inc., Mountainside, NY) according to the manufactor's guidelines. The antibody for this assay was highly specific with less than $5 \%$ cross-reactivity with any potentially competing plasma steroids (DRG International). The test sensitivity was $0.3 \mu \mathrm{g} / \mathrm{dl}$, and intra- and interassay coefficients of variation were 5.3 and $9.8 \%$, respectively.

ACTH concentrations were determined in duplicate in $200 \mu 1$ plasma with an immunoradiometric assay (Nichols Institute Diagnostics, San Juan Capistrano, CA, USA) that has been validated for animal specimens (Nichols Insstitute Diagnostics, Geneva, Switzerland) and has no cross-reactivities with $\alpha$-MSH, $\beta$-MSH, $\beta$ endorphin or $\beta$-LPH [29]. The intra- and interassay coefficients of variance were 3.2 and $7.8 \%$, and the assay sensitivity was $1.6 \mathrm{pg} / \mathrm{ml}$.

\section{Statistics}

Statistical analysis was done with $S A S^{\circledR}$, release 8.2. The model used for the analyses was a general linear model $Y=X \bullet \beta+\varepsilon$, where $Y$ denotes the vector of observations of a investigated trait, $X$ the known design matrix of the vector $\beta$ of the fixed effects on this trait (total mean, levels of the factors group (control, experiment), phase of pregnancy $\left(1^{\text {st }}, 2^{\text {nd }}\right.$ and $3^{\text {rd }}$ trimester), day of experiment within the pregnancy phase and all interactions between these factors), and $\varepsilon$ is the vector of random errors, with expectation $\mathrm{E}(\varepsilon)=0$ and covariance matrix $\mathrm{V}(\varepsilon)=\mathrm{R}$. Repeated measures on the animals (day of experiment within the pregnancy phase) were taken into account by the repeated statements of the procedures mixed (continuous data) or Genmod (count data; Poisson distribution) in SAS/ 
STAT software (SAS Institute Inc., 1999). The significance of each of the main effects and the interactions in the model was tested [type III F-tests (proc mixed); Wald statistic (proc Genmod)]. The model for the cortisol concentrations in fetuses included the fixed factors treatment, gender, blood vessel, the corresponding interactions and the factor sow nested within treatment as a random variable. For each variable, LSMeans and SE were calculated to display the results. Additionally, all pairwise differences between the LS-means were tested using the PDIFF-option in the LSMEANSstatement of proc Mixed and proc Genmod. The calculation of pulses and their further characterization was performed by the PULSAR program [30].

\section{Results}

All sows have continued pregnancy till Caesarean section or parturition, respectively. The procedure of catheterization at the $1^{\text {st }}, 2^{\text {nd }}$ and $3^{\text {rd }}$ $\mathrm{TP}$, and the frequent blood sampling every $10 \mathrm{~min}$ throughout six hours on each treatment day did not affect the progress of pregnancy. The number of fetuses/piglets (13.7 \pm 0.6 in ACTH treated vs. 13.1 \pm 0.6 in Control sows), the number of intact fetuses/liveborn piglets ( $12.7 \pm 0.6$ vs. $12.7 \pm 0.5)$, and the mean fetus/piglets weight $(1.10 \pm 0.02$ vs. $1.20 \pm 0.09 \mathrm{~kg}$ ) were obviously not influenced by repeated ACTH application.

The application of ACTH to sows caused a significant increase of plasma cortisol concentrations after $30 \mathrm{~min}$ lasting up to $360\left(3^{\text {rd }}\right.$ $\mathrm{TP})$ and $480 \mathrm{~min}\left(2^{\text {nd }} \mathrm{TP}\right.$; effect of treatment, and treatment by sampling time, $\mathrm{p}<0.001)$. Maximum cortisol levels ( $247.0 \pm 18.8$ to $276.5 \pm 17.2 \mathrm{nmol} / \mathrm{l})$ were reached between 120 and $180 \mathrm{~min}$. As an example, Figure 1 demonstrates plasma cortisol levels after ACTH and saline application at $3^{\text {rd }} \mathrm{TP}$.

The basal LH levels ranged in all sows between 0.11 and $0.16 \mathrm{ng} / \mathrm{ml}$ with differences between trimester of pregnancy and treatment groups (Table 1). The highest basal LH level was found during the $2^{\text {nd }} \mathrm{TP}$ in $\mathrm{ACTH}$ treated and during the $2^{\text {nd }}$ and $3^{\text {rd }}$ TP in Control sows.

The LH amount released (AUC over baseline) was higher in the $3^{\text {rd }}$ compared to $1^{\text {st }}$ and $2^{\text {nd }}$ trimester of pregnancy both for ACTH and saline treated animals, and differences were obtained between ACTH and Controls at the $2^{\text {nd }}$ and $3^{\text {rd }} \mathrm{TP}$. A pulsatile LH release pattern was evident throughout each trimester. The number of LH pulses $/ 6 \mathrm{~h}$ of saline treated Controls increased with ongoing pregnancy and decreased to the $3^{\text {rd }} \mathrm{TP}$

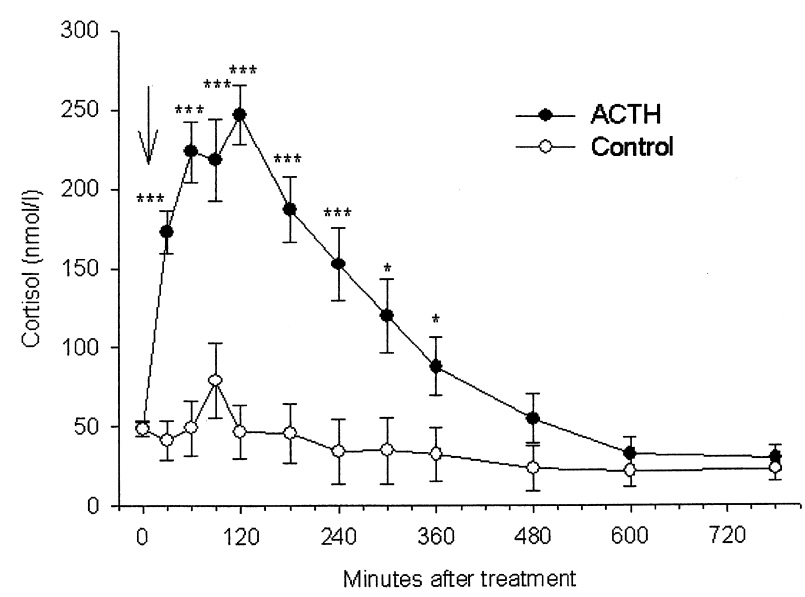

Fig. 1. Plasma cortisol concentrations before and after ACTH or saline injection $(\downarrow)$ in pregnant gilts during $3^{\text {rd }}$ trimester of pregnancy. Data represent LSMeans \pm SE. * and ${ }^{* * *}$ : $\mathrm{p}<0.05$ and 0.001 , respectively.

Table 1. Basal LH level, LH amount over baseline, LH pulse number, LH amount in pulses and progesterone level (LSMeans \pm SE) in ACTH treated $(n=13)$ and Control sows $(n=3)$ at $1^{\text {st }}, 2^{\text {nd }}$ and $3^{\text {rd }}$ trimester of pregnancy

\begin{tabular}{lcccccc}
\hline \multirow{2}{*}{ Parameter } & \multicolumn{2}{c}{$1^{\text {st }}$ trimester } & \multicolumn{2}{c}{$2^{\text {nd }}$ trimester } & \multicolumn{2}{c}{$3^{\text {rd }}$ trimester } \\
& ACTH & Control & ACTH & Control & ACTH & Control \\
\hline LH basal $(\mathrm{ng} / \mathrm{ml})$ & $0.14 \pm 0.01^{\mathrm{a}, \mathrm{A}}$ & $0.11 \pm 0.01^{\mathrm{b}, \mathrm{D}}$ & $0.16 \pm 0,01^{\mathrm{a}, \mathrm{B}}$ & $0.15 \pm 0.01^{\mathrm{b}, \mathrm{E}}$ & $0.11 \pm 0.01^{\mathrm{a}, \mathrm{C}}$ & $0.16 \pm 0.01^{\mathrm{b}, \mathrm{E}}$ \\
LH over baseline $(\mathrm{ng} / \mathrm{ml})$ & $0.5 \pm 0.1^{\mathrm{A}}$ & $0.6 \pm 0.1^{\mathrm{D}}$ & $0.4 \pm 0.1^{\mathrm{a}, \mathrm{A}}$ & $1.3 \pm 0.1^{\mathrm{b}, \mathrm{E}}$ & $1.2_{0.2^{\mathrm{a}, \mathrm{B}}}$ & $2.3 \pm 0.2^{\mathrm{b}, \mathrm{F}}$ \\
Number of LH pulses & $1.3 \pm 0.2^{\mathrm{a}}$ & $1.3 \pm 0.1^{\mathrm{D}}$ & $1.5 \pm 0.1^{\mathrm{a}, \mathrm{A}}$ & $2.0 \pm 0.1^{\mathrm{b}, \mathrm{E}}$ & $0.8 \pm 0.2^{\mathrm{a}, \mathrm{B}}$ & $1.4 \pm 0.1^{\mathrm{b}, \mathrm{D}, \mathrm{F}}$ \\
LH pulse $(\mathrm{ng} / \mathrm{ml})$ & $0.3 \pm 0.1^{\mathrm{A}}$ & $0.5 \pm 0.1^{\mathrm{D}}$ & $0.3 \pm 0.1^{\mathrm{a}, \mathrm{A}}$ & $0.6 \pm 0.1^{\mathrm{b}, \mathrm{D}}$ & $1.1_{0.11^{\mathrm{a}, \mathrm{B}}}$ & $1.7 \pm 0.1^{\mathrm{b}, \mathrm{E}}$ \\
Progesterone $(\mathrm{ng} / \mathrm{ml})$ & $30.0 \pm 0.9^{\mathrm{a}, \mathrm{A}}$ & $24.4 \pm 0.7^{\mathrm{b}, \mathrm{D}}$ & $35.5 \pm 0.9^{\mathrm{a}, \mathrm{B}}$ & $29.1 \pm 1.0^{\mathrm{b}, \mathrm{E}}$ & $13.6 \pm 0.2^{\mathrm{a}, \mathrm{C}}$ & $13.1 \pm 0.1^{\mathrm{b}, \mathrm{F}}$ \\
\hline
\end{tabular}

$\mathrm{a}, \mathrm{b}$ within a row denotes significant differences $(\mathrm{p}<0.05)$ between ACTH and controls within each trimester.

$A, B, C$ and ${ }^{D, E, F}$ within a row denotes significant differences $(p<0.05)$ between trimesters of ACTH and controls, respectively. 

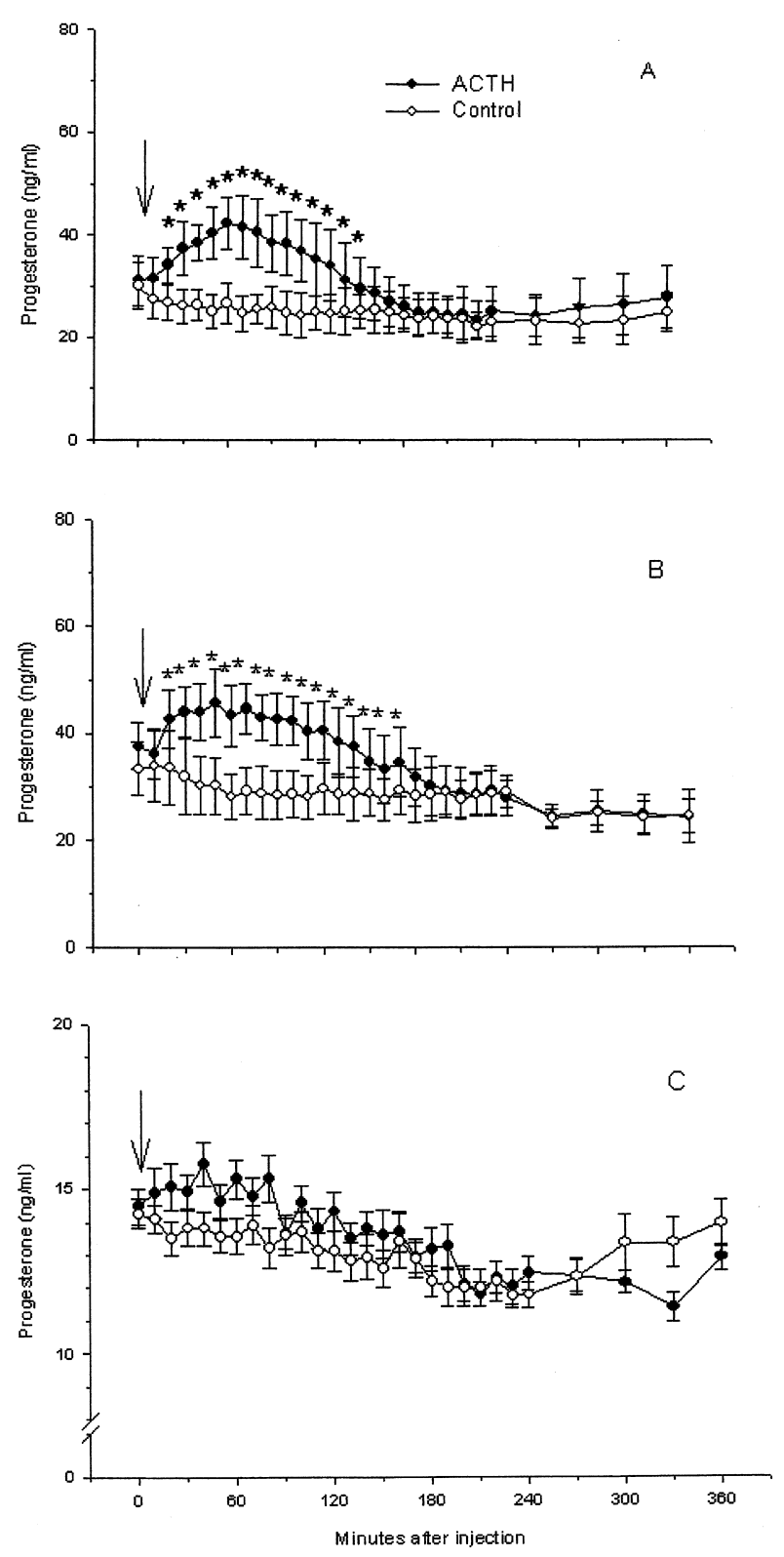

Fig. 2. Plasma progesterone concentrations before and after ACTH or saline injection $(\downarrow)$ in pregnant gilts at the $1^{\text {st }}(\mathrm{A}), 2^{\text {nd }}(\mathrm{B})$ and $3^{\text {rd }}(\mathrm{C})$ trimester of pregnancy. Data represent LSMeans \pm SE. ${ }^{*} \mathrm{p}<0.05$.

$(\mathrm{p}<0.05)$. After ACTH treatment the number of $\mathrm{LH}$ pulses left unchanged in the $1^{\text {st }}$ and $2^{\text {nd }}$ trimester and decreased to the $3^{\text {rd }}$ one. The LH pulse number was lower $(\mathrm{p}<0.05)$ after ACTH at the $2^{\text {nd }}$ and $3^{\text {rd }} \mathrm{TP}$ compared to saline treated sows. Furthermore, the LH amount released in a pulse was higher in Controls as in ACTH treated sows at the $2^{\text {nd }}$ and $3^{\text {rd }}$
TP. While LH pulse number was decreasing to the $3^{\text {rd }} \mathrm{TP}$ in each treatment group, the LH amount of each pulse was increasing, however.

The analysis of plasma $\mathrm{P}_{4}$ did not reveal signs of a pulsatile release. The mean $\mathrm{P}_{4}$ level increased from the $1^{\text {st }}$ to $2^{\text {nd }} \mathrm{TP}$ and was lower at the last trimester of pregnancy (Table $1, \mathrm{p}<0.05)$. In ACTH treated sows, the average progesterone concentrations were always higher as in Controls. Progesterone significantly increased after each ACTH injection commencing within $20 \mathrm{~min}$ and remaining elevated for $150-170$ min during the $1^{\text {st }}$ and $2^{\text {nd }}$, but not during the $3^{\text {rd }}$ trimester of pregnancy. This effect was not observed in Controls (Fig. 2).

In fetuses $(\mathrm{n}=87)$ recovered $3 \mathrm{~h}$ after ACTH $\left(2^{\text {nd }}\right.$ TP, day 65; EXP 4), the plasma cortisol concentrations were significantly increased in umbilical vein and artery, and in periphery compared to controls (Table 2). Such effect was not observed in fetuses $(n=24)$ which mothers were subjected to repeated ACTH injection from day 85 to 101 and recovered on day 105 of pregnancy. Plasma ACTH concentrations in the umbilical vein did not differ in fetuses of both treatment groups during $2^{\text {nd }} \mathrm{TP}(34.5 \pm 10.2$ vs. $48.0 \pm 7.6 \mathrm{pg} / \mathrm{ml})$.

Postnatal LH-RH challenge tests on day 1 and day 28 p.p. induced LH surge in female piglets both of ACTH and saline treated sows, but surge parameters did not differ between treatment groups (Table 3). Only Control piglets had both a higher maximum $\mathrm{LH}$ concentration and $\mathrm{LH}$ amount released comparing day 28 and day 1 p.p. The basal LH of piglets whose mothers were submitted to ACTH during $2^{\text {nd }} \mathrm{TP}$ was lower as Controls on day 1 , but not on day 28 p.p. However in both treatment groups, the basal LH was always higher on day 1 as on day 28 p.p.

\section{Discussion}

One result of our study is that repeated stimulation of pregnant sows with ACTH during different trimesters of pregnancy causes adrenocortical activation with reiterable cortisol release. This effect was not observed in saline treated sows. The repeated administration of saline does not affect the pituitary-adrenocortical activity compared to untreated controls, indicating that the injection itself is not stress-inducing [31]. The 
Table 2. Plasma cortisol concentrations in sows $(n=12)$, and plasma cortisol and ACTH concentrations (LSMeans \pm SE) in fetuses ( $n=111)$ on days 65 and 105 of pregnancy following single or repeated ACTH application

\begin{tabular}{lcccc}
\hline & \multicolumn{2}{c}{ day 65 of pregnancy } & \multicolumn{2}{c}{ day 105 of pregnancy } \\
& ACTH & Control & ACTH & Control \\
\hline Cortisol in sows $(\mathrm{nmol} / \mathrm{l})$ & $402.2 \pm 21.3^{\mathrm{a}}$ & $72.6 \pm 21.3^{\mathrm{b}}$ & $230.8 \pm 39.7$ & $166.6 \pm 39.7$ \\
\hline Cortisol in fetuses $(\mathrm{nmol} / \mathrm{ml})$ & & & & \\
$\quad$ umbilical vein & $93.7 \pm 5.5^{\mathrm{a}}$ & $47.0 \pm 5.3^{\mathrm{b}}$ & $214.9 \pm 50.2$ & $309.0 \pm 50.2$ \\
umbilical artery & $95.7 \pm 5.4^{\mathrm{a}}$ & $66.4 \pm 5.4^{\mathrm{b}}$ & $242.8 \pm 55.8$ & $347.6 \pm 55.8$ \\
fetal peripheral plasma & $46.8 \pm 5.3^{\mathrm{c}}$ & $27.1 \pm 5.3^{\mathrm{d}}$ & $356.5 \pm 91.3$ & $451.1 \pm 91.3$ \\
\hline a:b $\mathrm{p}<0.01 ;{ }^{\mathrm{ccd}} \mathrm{p}=0.09$. & & & &
\end{tabular}

Table 3. Basal and maximum LH concentrations, and AUC of LH surge (LSMeans \pm SE) of piglets ( $n=$ 67) on days 1 and 28 post partum (p.p.)

\begin{tabular}{lcccr}
\hline & \multicolumn{2}{c}{ day 1 p.p. } & \multicolumn{2}{c}{ day 28 p.p. } \\
& ACTH & Control & ACTH & Control \\
\hline Maximum LH $(\mathrm{ng} / \mathrm{ml})$ & $7.2 \pm 0.8$ & $8.1 \pm 0.7^{\mathrm{C}}$ & $10.5 \pm 1.7$ & $13.6 \pm 2.2^{\mathrm{D}}$ \\
AUC of LH surge $(\mathrm{ng} / \mathrm{ml})$ & $23.5 \pm 2.7$ & $28.6 \pm 2.9^{\mathrm{C}}$ & $34.8 \pm 5.1$ & $42.8^{\mathrm{D}} \pm 4.9^{\mathrm{D}}$ \\
Basal LH $(\mathrm{ng} / \mathrm{ml})$ & $1.7 \pm 0.2^{\mathrm{a}, \mathrm{A}}$ & $2.3 \pm 0.2^{\mathrm{b}, \mathrm{C}}$ & $1.0 \pm 0.2^{\mathrm{B}}$ & $1.1 \pm 0.2^{\mathrm{D}}$ \\
\hline $\mathrm{A}, \mathrm{B}$ and $\mathrm{C}, \mathrm{D}$ within a row denotes significant differences $(\mathrm{p}<0.05)$ between days p.p. of ACTH and controls, \\
respectively. \\
a,b within a row denotes significant differences $(\mathrm{p}<0.05)$ between ACTH and controls within each day p.p.
\end{tabular}

exogenous ACTH treatment, which can be considered as a simplified "stress model", ascertains ACTH- and cortisol-related effects, and avoids stress-related effects of other systems, i.e. endogenous opoide peptides, catecholamines and prolactin. ACTH application has been shown to increase cortisol levels in swine [32-34]. The adrenocortical response to ACTH was consistent during each trimester of pregnancy and significantly increased cortisol levels were found at all days. No signs of habituation or sensitization were observed. Although maternal cortisol was elevated after repeated ACTH application by 100 $200 \%$ for more than $6 \mathrm{~h}$, no deleterious effects on pregnancy were found. Razdan et al. [35] found as well no influence of stress-like situation (food deprivation, ACTH application) on early fetal development.

Serious stress in sows' pregnancy may affect, however, placental metabolism and maternal blood levels of reproductive hormones, and impair fetal development. Studies have shown that hormones of the HPA axis are able to suppress gonadal function by inhibiting GnRH release [36]. CRF, ACTH and cortisol act on the hypothalamus to restrain the GnRH secretion or directly on the pituitary to inhibit gonadotropin responsiveness to GnRH. Furthermore, an involvement of endogenous opioid peptides (EOP) and some other compounds on LH secretion has been documented [37-39, reviews: 40, 41].

In pregnant sows, the concentration of LH has been reported to be low (between $0.25-0.50 \mathrm{ng} / \mathrm{ml}$ ), without differences throughout the entire pregnancy, but with some pulsatile fluctuation [23$26,42,43]$. To our knowledge, there are, only few data on the pattern of LH pulsatility throughout pregnancy in the pig [26] and, moreover, on its stress-induced changes.

The present results on the course of LH concentration during early, mid-and late pregnancy showed uniform basal levels between 0.11 and $0.16 \mathrm{ng} / \mathrm{ml}$, which are in the range reported previously [26, 42]. More LH (AUC over baseline) was released in controls with ongoing pregnancy but LH secretion was suppressed in ACTH treated sows commencing at the $2^{\text {nd }} \mathrm{TP}$. Nevertheless, a modest pulsatile release pattern was found in each period of pregnancy. LH pulse frequency increased from the $1^{\text {st }}$ to $2^{\text {nd }} \mathrm{TP}$ and 
decreased to late pregnancy. Kraeling et al. [26] reported also a higher number of LH peaks on days 30-70 of pregnancy compared with later period. Whereas ACTH did not affect the LH pulse frequency at the $1^{\text {st }} \mathrm{TP}$, the pulse number was decreased during the mid- and late pregnancy. The lack of ACTH-related influence on LH pulse secretion during the $1^{\text {st }}$ TP may be due to the transient elevation of estrogen level during early pregnancy having a strong negative feedback on LH release [44]. Therefore, an additional inhibition of LH pulse secretion by ACTH is omitted. Furthermore, the amount of LH released at each pulse was reduced of about $50 \%$ by ACTH treatment during the $2^{\text {nd }}$ and $3^{\text {rd }}$ trimester.

In the pig, $\mathrm{LH}$ is the main luteotropic factor from early to mid-gestation [23, 45, 46]. The lowfrequent pulsatile LH release found in our study and previously [23] seems to be crucial for proper function of porcine corpora lutea, which are the main source of progesterone and necessary for maintaining pregnancy $[5,47]$. Data summarized by Knight [4] indicate that the porcine placenta produces also large quantities of progesterone throughout gestation which are utilized locally and/or rapidly metabolized through androgens to estrogens. LH binding to uterine receptors may be involved in placental progesterone production [review: 48]. The lower LH availability after ACTH detected at the $2^{\text {nd }}$ and $3^{\text {rd }} \mathrm{TP}$ could result the amount of secreted luteal progesterone. The results, however, are opposing. We found elevated steroid levels for about $3 \mathrm{~h}$ after ACTH application both during the $1^{\text {st }}$ trimester, where $\mathrm{LH}$ was not affected by $\mathrm{ACTH}$, and during the $2^{\text {nd }} \mathrm{TP}$, where $\mathrm{LH}$ was influenced. The source of this additional progesterone is assumed to be the adrenals [49]. This supposition is supported by likewise elevated concentrations of $17 \alpha-\mathrm{OHP}$, a related steroid, after each ACTH administration (44). No ACTH-related progesterone increase was found during the $3^{\text {rd }} \mathrm{TP}$, although LH and LH frequency were influenced. It remains open whether the lacking progesterone increase after ACTH is the result of lower capacity of the adrenals, corpora lutea and/or placenta. However, it has to keep in mind that a complex of luteotropic components ( $\mathrm{LH}$, prolactin, endogenous opiods) and its interaction with progesterone is involved in late gestation in the sow [42, 50-52].

It is well established that exogenous ACTH effects an increase in cortisol. At pregnancy, the placenta has a changing capacity to convert corticoids and thus to protect fetuses [53-56]. In stressful situation, excess of cortisol may force this protective mechanism. It remains speculative if transiently elevated progesterone levels, as observed in our study, contribute to increased cortisol levels by blocking cortisol-transforming activities of $11 \beta$-hydroxysteroid-dehydrogenase- 2 (11 $\beta$-HSD-2) [57] or by displacement from plasma protein binding [58]. Varying activities for $11 \beta$ HSD are also present in corpora lutea $[58,59]$. Thus, the function of the ovary in pregnant sows could be affected by exogenous ACTH.

A significant increase of cortisol concentrations in the umbilical vein and artery of fetuses was detected $3 \mathrm{~h}$ after ACTH application to sows on day 65 of pregnancy compared to Controls. This may lead to a higher exposure of cortisol in the fetuses. Generally, umbilical venous cortisol levels were lower compared to maternal plasma cortisol concentrations both in treated and control animals, demonstrating the mechanism to inactivate cortisol by the placenta $[60,61]$. The higher cortisol concentrations in umbilical artery in controls fetuses may also reflect the ability of the fetal adrenal to release cortisol at this time. The fetal adrenal is able to respond to ACTH at 75 days, suggesting an active HPA axis at this time [60,62]. However, in fetuses which mothers were subjected to repeated ACTH treatment during the $3^{\text {rd }}$ trimester, no differences were found both of umbilical cortisol between treated and control fetuses and of maternal and fetal cortisol on day 105 of pregnancy. One explanation is that the mature fetal adrenal secretes enhanced cortisol in the peripartal period.

It was shown that stress can alter aspects of immune function in pigs [6,63-65] but to our knowledge, stress-related gonadotropin alteration in neonate piglets are missing. In neonate female piglets at the age of 6-7 days the mean $\mathrm{LH}$ concentration was $2.3 \pm 0.2 \mathrm{ng} / \mathrm{ml}$ [66]. Similar results were obtained in female Control piglets on day 1 p.p. in our study. However, those from ACTH treated mothers had a lower LH level. It is still speculative if ACTH-related steroids feedback actions are involved. On day 28 p.p. no differences were found between ACTH and Control piglets, but in both groups the basal LH concentrations were decreased compared to day 1 . On the other 
side, all piglets demonstrate a LH surge after LHRH challenge (LH surge amount: 23.5 to $42.8 \mathrm{ng}$ / $\mathrm{ml}$ ) with no differences between treatments. Consequently, neonate female pigs are able to release LH from the pituitary and as demonstrated by Ponzilius et al., [24] in a pulsatile manner as well. Our results were obtained with a limited number of piglets and pigs which mothers were subjected to repeated $A C T H$ during the $2^{\text {nd }} T P$, only. Nevertheless, an impact of ACTH on LH system may be evident leading to reproductive alterations during lifetime.

In summary, results of this study showed that repeated administration of ACTH ("stress-like simulation") to pregnant sows is able to influence the release pattern of maternal reproductive hormones, and these effects are dependent on the stage of pregnancy. Furthermore, it was shown that maternal cortisol can cross the placenta during gestation and thus may affect maternal-fetal interactions and, as a result, reproductive function of offspring.

\section{References}

1. Sapolsky RM, Romero LM, Muck AU. How do glucocorticoids influence stress response? Integrating permissive, suppressive, stimulatory and preparative actions. Endocr Rev 2000; 21: 55-89.

2. Claus R, Raab S, Lacorn M. Activities of $11 \beta$ hydroxysteroid dehydrogenase 2 in different regions of the intestinal tract of pigs. Exp Clin Endocrinol Diabetes 2001; 109: 374-377.

3. Gloddek J, Lohrer P, Stalla J, Arzt E, Stalla GK, Renner U. The intrapituitary stimulatory effect of lipopolysacccharide on ACTH secretion is mediated by paracrine-acting IL-6. Exp Clin Endocrinol Diabetes 2001; 109: 410-415.

4. Knight JW. Aspects of placental estrogen synthesis in the pig. Exp Clin Endocrinol 1994; 102: 175-184.

5. Pilon N, Daneau I, Brisson C, Ethier JF, Lussier JG, Silversides DW. Porcine and bovine steroidogenic acute regulatory protein (StAR) gene expression during gestation. Endocrinology 1997; 138: 10851091.

6. Haussmann MF, Carroll JA, Weesner GD, Daniels MJ, Matteri RL, Lay Jr DC. Administration of ACTH to restrained, pregnant sows alters their pig's hypothalamic-pituitary-adrenal (HPA) axis. J Anim Sci 2000; 78: 2399-2411.

7. Ashworth CJ, Finch AM, Page KR, Nwagwu MO, McArdle HJ. Causes and consequences of fetal growth retardation in pigs. Reproduction 2001; Suppl 58: 233-246.

8. Otten W, Kanitz E, Tuchscherer M, Nürnberg G. Effects of prenatal restraint stress on hypothalamicpituitary-adrenocortical and sympathoadrenomedullary axis in neonatal pigs. Anim Sci 2001; 73: 279-287.

9. Fonseca ESM, Massoco CO, Palermo-Neto J. Effects of prenantal stress on stress-induced changes in behavior and macrophage activity of mice. Physiol Behav 2002; 77: 205-215.

10. Matthews SG. Antenatal glucocorticoids and programming of the developing CNS. Pediatr Res
2000; 47: 291-300.

11. Borwick SC, Rae MT, Brooks J, McNeilly AS, Racey PA, Rhind SM. Undernutrition of ewe lambs in utero and in early post-natal life does not affect hypothalamic-pituitary function in aldhood. Anim Reprod Sci 2003; 77: 61-70.

12. Van der Lende T, van Rens BTTM. Critical periods for foetal mortality in gilts identified bi analysing the length distribution of mummified foetuses and frequency of non-fresh stillborn piglets. Anim Reprod Sci 2003; 75: 141-150.

13. Tilbrook AJ, Turner AI, Clarke IJ. Stress and reproduction: central mechanisms and sex differences in non-rodent species. Stress 2002; 5: 83100.

14. Turner AI, Hemsworth PH, Hughes PE, Tilbrook AJ. Repeated acute activation of the hypothalamopituitary adrenal axis prior to and during estrus did not reproductive performance in gilts. Biol Reprod 1998; 58: 1458-1462.

15. Hopster H, van der Werf JTN, Erkens JHF, Blokhuis HJ. Effects of repeated jugular puncture on plasma cortisol concentrations in loose-housed dairy cows. J Anim Sci 1999; 77: 708-714.

16. Kanitz E, Otten W, Tuchscherer M, Nürnberg G. Effects of age and maternal reactivity on the stress response of the pituitary-adrenocortical axis and the sympathetic nervous system in neonatal pigs. Anim Sci 1999; 68: 519-526.

17. Turner AI, Hemsworth PH, Canny BJ, Tilbrook AJ. Sustained but not repeated acute elevation of cortisol impaired the luteinizing hormone surge, estrus, and ovulation in gilts. Biol Reprod 1999; 61: 614-620.

18. Ladewig J. Chronic intermittent stress: a model for the study of long-term stressors. In: Moberg GP and Mench JA (eds.), The Biology of Stress CAB International; 2000: 159-169.

19. Razdan P, Mwanza AN, Kindahl H, RodriguezMartinez $H$, Hulten $F$, Einarsson S. Effect of 
repeated ACTH-stimulation on early embryonic development and hormonal profiles in sows. Anim Reprod Sci 2002; 70: 127-137.

20. Estienne MJ, Barb CR, Kesner JS. Luteinizing hormone secretion in hypophysial stalk-transected gilts given hydrocortisone acetate and pulsatile gonadotropin-releasing hormone. Domest Anim Endocrinol 1991; 8: 407-414.

21. Macfarlane MS, Breen KM, Sakurai H, Adams BM, Adams TE. Effect of duration of infusion of stresslike concentrations of cortisol on follicular development and the preovulatory surge of LH in sheep. Anim Reprod Sci 2000; 63: 167-175.

22. Dobson H, Smith RF. What is stress, and how does it affect reproduction? Anim Reprod Sci 2000; 60-61: 743-752.

23. Ziecik A, Tilton JE, Weigl R, Williams GL. Plasma luteinizing hormone during pregnancy in the pig. Anim Reprod Sci 1982/1983; 5: 213-218.

24. Ponzilius KH, Parvizi N, Elseasser F, Ellendorff F. Ontogeny of secretory patterns of LH release and effects of gonadectomy in the chronically catheterised pig fetus and neonate. Biol Reprod 1986; 34: 602-612.

25. Kanitz E, Spitschak K, Schneider F. Erste Ergebnisse der Bestimmung des luteinisierenden Hormons während der frühen Trächtigkeit beim Schwein. Arch Exper Vet Med 1987; 41: 114-120.

26. Kraeling RR, Barb CR, Rampacek GB. Prolactin and luteinizing hormone secretion in the pregnant pig. J Anim Sci 1992; 70: 3521-3527.

27. Rodriguez H, Kunavongkrit A. Chronical venous catheterization for frequent blood sampling in unrestraint pigs. Acta Vet Scand 1983; 24: 318-320.

28. Schneider F, Bellmann A, Becker F, Bambang Poernomo S, Rehfeldt C, Nürnberg G, Kanitz W. Gonadotropin release in periovulatory heifers after GnRH analogs measured by two types of immunoassays. Exp Clin Endocrinol Diabetes 2002; 111: 235-245.

29. Zahradnik R, Brennan G, Hutchinson JS, Odell WD. Immunoradiometric assay of corticotropin with use of avidin-biotin separation. Clin Chem 1989; 35: 804-807.

30. Merriam GR, Wachter KW. Algorithms for the study of episodic hormone secretion. Am J Physiol 1982; 243: E310-E318.

31. Otten W, Kanitz E, Tuchscherer M, Schneider F, Brüssow K-P. Effects of adrenocorticotropin stimulation on cortisol dynamics of pregnant gilts and their fetuses: implications for prenatal stress studies. Theriogenology 2004; 61: 1649-1659.

32. Hennessey DP, Stelmasiak T, Johnston NE, Jackson PN, Outch KH. Consistent capacity for adrenocortical response to ACTH administration in pigs. Am J Vet Res 1988; 49: 1276-1283.

33. Borell von E, Ladewig J. Altered adrenocortical response to acute stressors or ACTH in intensively housed pigs. Dom Anim Endocrinol 1989; 6: 299-309.

34. Mwanza AM, Madej A, Kindal H, Lundeheim N, Einarsson S. Plasma levels of cortisol, progesterone, oestradiol- $17 \beta$ and prostaglandin $\mathrm{F}_{2 \alpha}$ metabolite after ACTH (Synacthen ${ }^{\circledR}$ Depot) administration in ovariectomized gilts. J Vet Med A 2000; 47: 193-200.

35. Razdan P, Tummaruk $\mathbf{P}$, Kindahl H, RodriguezMartinez H, Hulten F, Einarsson S. The impact of induced stress during days 13 and 14 of pregnancy on the composition of allantoic fluid and conceptus development in sows. Theriogenology 2004; 61: 757767.

36. Rivier C, Rivest S. Effect of stress on the activity of the hypothalamic-pituitary-gonadal axis: peripheral and central mechanisms (Review). Biol Reprod 1991; 45: 523-532.

37. Chang WJ, Barb CR, Kraeling RR, Rampacek GB, Leshin LS. Involvement of the central noradrenergic system in opioid modulation of luteinizing hormone and prolactin secretion in the pig. Biol Reprod 1993; 49: 176-180.

38. Cosgrove JR, de Rensis F, Foxcroft GR. Opioidergic pathways in animal reproduction: their role and effects of their pharmacological control. Anim Reprod Sci 1993; 33: 373-392.

39. Faletti AG, Mastronardi CA, Lomniczi A, Seilicovich A, Gimeno M, McCann SM, Rettori V. Endorphin blocks luteinizing hormone-releasing hormone release by inhibiting the nitricoxidergic pathway controlling its release. Proc Natl Acad Sci USA 1999; 96: 1722-1726.

40. Brann DW, Mahesh VB. Excitatory amino acids: evidence for a role in the control of reproduction and anterior pituitary hormone secretion. Endocr Rev 1997; 18: 678-700.

41. Parvizi N. Neuroendocrine regulation of gonadotropins in the male and the female. Anim Reprod Sci 2000; 60-61: 31-47.

42. Willis HJ, Crosgrove JR, Foxcroft GR. Opioidergic control of luteinizing hormone and prolactin secretion in late gestation in the sow. Biol Reprod 1996; 55: 318-324.

43. Rzucidlo SJ, Weigl RM, Tilton JE. Myometrial LH/ hCG receptors during the estrous cycle and pregnancy in pigs. Anim Reprod Sci 1998; 51: 249257.

44. Schneider F, Brüssow K-P, Kanitz E, Otten W, Tuchscherer A. Maternal reproductive hormone levels after repeated ACTH application to pregnant gilts. Anim Reprod Sci 2004; 81: 313-327.

45. Szafranska B, Ziecik AJ. Effect of bromocriptine administration during mid-pregnancy on the ovary function in the pig. Exp Clin Endocrinol 1990; 96: 317320.

46. Szafranska B, Grazul-Bilska AT, Przala J. Effect of $\mathrm{LH}$ and prolactin on steroid secretion by perfused 
luteal tissue from pregnant gilts with immunoneutralization of LH. Arch Vet Pol 1992; 32: 7-15.

47. Bazer FW, Roberts RM, Thatcher WW. Actions of hormones on the uterus and effects on conceptus development. J Anim Sci 1979; 49 (Suppl): 35-45.

48. Shemesh M. Actions of gonadotrophins on the uterus. Reproduction 2001; 121: 835-842.

49. Tsuma VT, Einarsson S, Madej A, Kindahl H, Lundeheim $\mathbf{N}$. Effect of food deprivation during early pregnancy on endocrine changes in primiparous sows. Anim Reprod Sci 1996; 41: 267278.

50. Jammes H, Schirar A, Djiane J. Differential patterns in luteal prolactin and $\mathrm{LH}$ receptors during pregnancy in sows and ewes. J Reprod Fertil 1985; 73: 27-35.

51. Gregoraszczuk EL. Different response of porcine large and small luteal cells to PRL in terms of progesterone and estradiol secretion in vitro. Exp Clin Endocrinol 1990; 96: 234-237.

52. Taverne $\mathbf{M}$, Bevers $\mathbf{M}$, Bradshaw JMC, Dieleman SJ, Willemse AH, Porter DG. Plasma concentrations of prolactin, progesterone, relaxin and oestradiol-17 $\beta$ in sows treated with progesterone, bromocriptine or indomethacin during late pregnancy. J Reprod Fertil 1982; 65: 85-96.

53. Brown RW, Diaz R, Robson AC, Kotelevtsev YV, Mullins JJ, Kaufman MH, Seckl JR. The ontogeny of $11 \beta$-hydroxysteroid dehydrogenase type 2 and mineralocorticoid receptor gene expression reveal intricate control of glucocorticoid action in development. Endocrinology 1996; 137: 794-797.

54. Klemcke HG, Christenson RK. Porcine placental 11beta-hydroxysteroid dehydrogenase activity. Biol Reprod 1996; 55: 217-223.

55. Burton PJ, Waddell BJ. Dual function of $11 \beta$ hydroxysteroid dehydrogenase in placenta: modulating placental glucocorticoid passage and local steroid action (Minireview). Biol Reprod 1999; 60: 234-240.

56. Klemcke HG. Dehydrogenase and oxoreductase activities of porcine placental 11beta- hydroxysteroid dehydrogenase. Life Sci 2000; 66: 1045-1052.

57. Quinkler M, Johanssen S, Grossmann C, Bähr V, Müller M, Oelkers W, Diederich S. Progesterone metabolism in the human kidney and inhibition of 11beta-hydroxysteroid dehydrogenase type 2 by progesterone and its metabolites. J Clin Endocrinol Metab 1999; 84: 4165-4171.

58. Andersen YC. Possibile new mechanism of cortisol action in female reproductive organs: physiological implications of the free hormone hypothesis. I Endocrinol 2002; 173: 211-217.

59. Waddell BJ, Benedictsson R, Seckl JR. 11 $\beta$ Hydroxysteroid dehydrogenase type 2 in the rat corpus luteum: induction of messenger ribonucleic acid expression and bioactivity coincident with luteal regression. Endocrinology 1996; 137: 53865391.

60. Klemcke HG, Christenson RK. Porcine fetal and maternal adrenocorticotropic hormone and corticosteroid concentrations during gestation and their relation to fetal size. Biol Reprod 1997; 57: 99 106.

61. Welberg LA, Seckl JR. Prenatal stress, glucocorticoids and the programming of the brain. J Neuroendocrinol 2001; 13: 113-128.

62. Silver M, Fowden AL. Pituitary-adrenocortical activity in the fetal pig in the last third of gestation. J Exp Physiol 1989; 74: 197-206.

63. Kelley KW. Stress and immune function: a bibliographic review. Ann Rech Vet 1980; 11: 445478.

64. Morrow-Tesch JL, McGlone JJ, Salak JL. Heat and social stress effects on pig immune measures. J Anim Sci 1994; 72: 2599-2609.

65. Tuchscherer M, Kanitz E, Otten W, Tuchscherer A. Effects of prenatal stress on hypothalamic-pituitaryadrenocortical and sympatho-adrenomedullary axis in neonatal pigs. Anim Sci 2002; 86: 195-203.

66. Prunier A, Ellendorff F, Parvizi N. Opiod action on luteinizing hormone secretion in newborn pigs: paradoxial effect of nalaxone. J Dev Physiol 1990; 14: 221-227. 